\title{
Effects of $\mathrm{NO}_{3}^{-}$Availability on Total Productivity, Root Morphology, Photosynthesis and Nitrogen Metabolism of Lettuce (Lactuca sativa L.) Recombinant Inbred Lines
}

\author{
J. He ${ }^{*}$, S.-F. Goh and L. Qin
}

Natural Sciences and Science Education Academic Group, National Institute of Education, Nanyang Technological University, 1 Nanyang Walk, 637616, Singapore

\begin{abstract}
We have identified certain heat-resistant (HR) and heat-sensitive (HS) lettuce (Lactuca sativa) recombinant inbred lines (RILs) from 113 lines under hot ambient temperature by studying the root morphology, shoot and root productivity. Except for temperature, one of the other major determinants of root morphology is nitrate $\left(\mathrm{NO}_{3}{ }^{-}\right)$availability. In this study, total productivity, root morphology, photosynthesis and nitrogen (N) metabolism of two RILs, 168 HS and 200 HR were studied under full $\mathrm{N}\left(100 \% \mathrm{NO}_{3}{ }^{-}\right),+\mathrm{N}\left(125 \% \mathrm{NO}_{3}{ }^{-}\right)$and $-\mathrm{N}\left(50 \% \mathrm{NO}_{3}{ }^{-}\right)$. The shoot and root productivity of both RILs under $+\mathrm{N}$ and $-\mathrm{N}$ treatments declined compared to those of full $\mathrm{N}$ plants. Reductions in root length, root surface area and total number of root tips were observed in $168 \mathrm{HS}$ plants under both $+\mathrm{N}$ and $-\mathrm{N}$ treatments. For $200 \mathrm{HR}$ plants, they all had similar values of root parameters regardless of $\mathrm{N}$ treatments. There were no significant differences in the light saturated $\mathrm{CO}_{2}$ assimilation $\left(A_{\text {sat }}\right)$ and stomatal conductance $\left(g_{s}\right.$ sat $)$ between two RIL plants For each lettuce RIL, no differences in total chlorophyll $(\mathrm{Chl})$ content and $\mathrm{Chl} \mathrm{a} / \mathrm{b}$ ratio were observed among the different $\mathrm{N}$ treatment. For both lettuce RILs, shoot $\mathrm{NO}_{3}{ }^{-}$concentration was highest in $+\mathrm{N}$ followed by full $\mathrm{N}$ plants and $-\mathrm{N}$ plants had the lowest values. There were no differences in root $\mathrm{NO}_{3}{ }^{-}$concentration between $+\mathrm{N}$ and full $\mathrm{N}$ plants but root $\mathrm{NO}_{3}{ }^{-}$concentration was significantly lower in $-\mathrm{N}$ plants than in $+\mathrm{N}$ and full $\mathrm{N}$ plants. For shoot total reduced $\mathrm{N},+\mathrm{N}$ plants had significantly higher concentration in both RILs compared to those of full $\mathrm{N}$ and $-\mathrm{N}$ plants. All plants had similar root total reduced $\mathrm{N}$ concentrations except for 168 HS under $-\mathrm{N}$ condition, which had significantly lower total reduced $\mathrm{N}$ concentrations. Differences in shoot maximal nitrate reductase (NR) activity among the different $\mathrm{N}$ treated plants were similar to those of total reduced $\mathrm{N}$ concentration. The relationships among $\mathrm{NO}_{3}{ }^{-}$availability, root morphology, productivity, photosynthesis and $\mathrm{N}$ metabolism were discussed.
\end{abstract}

Keywords: $\mathrm{NO}_{3}{ }^{-}$availability, $\mathrm{NO}_{3}{ }^{-}$reductase, photosynthesis, productivity, root morphology.

\section{INTRODUCTION}

Nitrogen $(\mathrm{N})$ is one of the most important minerals required for plant growth. The major $\mathrm{N}$ source in soil is nitrate $\left(\mathrm{NO}^{-}\right)$. Plant growth is most frequently limited by the availability of $\mathrm{NO}^{-}[1]$. It was reported that growth of lettuce increases when the external $\mathrm{N}$ supply increases [2]. Many studies have shown that there is a regulatory and sensing mechanism between the carbon (C) production and $\mathrm{N}$ metabolism as they are sinks for ATP and $\mathrm{NADPH}_{2}$ generated during photosynthesis [3].

$\mathrm{NO}_{3}{ }^{-}$is both a major $\mathrm{N}$ source for nutrition of plants and a signal to modulate plant development, suggesting that plant cells must have a sensor for $\mathrm{NO}_{3}{ }^{-}$availability [4]. Studies have shown that $\mathrm{NO}_{3}{ }^{-}$availability in the soil affects not only shoot and root production but also root morphology [5, 6]. For instance, the initiation and elongation of Arabidopsis lateral root development is stimulated by local availability of

*Address correspondence to this author at the Natural Sciences and Science Education Academic Group, National Institute of Education, Nanyang Technological University, 1 Nanyang Walk, 637616, Singapore;

Tel: 65-67903817; Fax: 65-68969432;

E-mail: jie.he@nie.edu.sg
$\mathrm{NO}_{3}^{-}$[7]. With lower $\mathrm{NO}_{3}^{-}$available to Arabidopsis thaliana, lateral root (LR) initiation was suppressed. However, plants supplied with high concentration of $\mathrm{NO}_{3}{ }^{-}$ showed that LR was initiated and elongated [8], which was due to increased influx of photosynthetic products at the site of $\mathrm{NO}_{3}{ }^{-}$uptake which is usually the roots [9]. It was also reported that birch (Betula pendula) plants allocate relatively less nutrients to the roots when $\mathrm{NO}_{3}{ }^{-}$is highly available in the soil [10]. These results indicate that the $\mathrm{N}$ uptake and assimilation is greatly promoted by increasing $\mathrm{C}$ supply. Therefore, $\mathrm{N}$ availability to the plants may directly or indirectly impact the $\mathrm{N}$ uptake and its assimilation.

$\mathrm{NO}_{3}{ }^{-}$is not used directly to synthesize amino acids in the plants. It is assimilated through a series of reduction catalysed by both nitrate reductase (NR) and nitrite reductase (NIR) into $\mathrm{NH}_{4}^{+}$which is then converted into amino acids and other organic $\mathrm{N}$ compounds [11-13]. In most grass species, the reduction of $\mathrm{NO}_{3}^{-}$by $\mathrm{NR}$ is observed predominantly in shoots [14]. Synthesis of NR has been studied and proven to be promoted by light, $\mathrm{NO}_{3}{ }^{-}$and photosynthesis $[13,15]$. It has been reported that tomato roots which were supplied with high $\mathrm{NO}_{3}^{-}$had maximum NR activity and $\mathrm{NO}_{3}^{-}$is believed to play a part in NR posttranslational regulation [16]. 
There is increasing use of fertilisers $\mathrm{N}$ in the cultivation of crops to ensure yield and concern about potential health risks of taking in excess $\mathrm{NO}_{3}^{-}$concentration in lettuce. Hence, optimising or even reducing the supply of $\mathrm{N}$ such as $\mathrm{NO}_{3}^{-}$to the vegetable crops becomes critical. In addition, there is more awareness about the impact of climate change to food safety and food security. It will be cost effective if we are able to identify crops that are more heat resistant yet able to produce high yield given lesser $\mathrm{NO}_{3}{ }^{-}$supplied to the growth mediate. In our previous study, some heat resistant (HR) and heat sensitive (HS) RILs of Latuca sativa have been identified from 113 lines [17, 18]. In this study, two lettuce RILs, namely $168 \mathrm{HS}$ and $200 \mathrm{HR}$, were supplied with different concentrations of $\mathrm{NO}_{3}{ }^{-}$. The effects of $\mathrm{NO}_{3}{ }^{-}$ availability on productivity, root morphology, photosynthetic $\mathrm{CO}_{2}$ assimilation and $\mathrm{N}$ metabolism were investigated.

\section{MATERIALS AND METHODS}

\section{Plant Materials and Culture Methods}

Lettuce RILs ( $\mathrm{F}_{9}$ generation) were obtained from repeated crosses between HS L. sativa (cv. 'Salinas') and HR L. serriola (accession UC96US23). Previously identified HR (Line 200) and HS (Line 168) RILs were used for this study. After germination for three days, the plants were then grown in the greenhouse for 4 days for acclimatization before transplanting onto the hydroponic trays. All plants were exposed to ambient temperature fluctuating from $26-36^{\circ} \mathrm{C}$ under $100 \%$ of full sunlight with average maximal photon flux density (PPFD) of 1000 to $1200 \mu \mathrm{mol} \mathrm{m}^{-2} \mathrm{~s}^{-1}$ and $75 \%$ of relative humidity. Plants were divided into three groups and each of them was supplied with one of the three different $\mathrm{NO}_{3}{ }^{-}$concentrations: full $\mathrm{N}\left(100 \% \mathrm{NO}_{3}{ }^{-}\right),+\mathrm{N}\left(125 \% \mathrm{NO}_{3}{ }^{-}\right)$ and $-\mathrm{N}\left(50 \% \mathrm{NO}_{3}{ }^{-}\right)$. Full $\mathrm{N}$ plants were supplied with full strength Netherlands Standard Composition. Nutrient solution conductivity and $\mathrm{pH}$ were maintained at $2 \pm 0.2 \mathrm{mS}$ and $6.5 \pm 0.5$, respectively. For $+\mathrm{N}$ treatment $\left(125 \% \mathrm{NO}_{3}{ }^{-}\right)$, nutrients solution was added with additional $65 \% \mathrm{HNO}_{3}$. For $\mathrm{N}$ treatment $\left(50 \% \mathrm{NO}_{3}{ }^{-}\right)$, supply for the $\mathrm{KNO}_{3}$ and $\mathrm{Ca}\left(\mathrm{NO}_{3}\right)_{2}$ were reduced by half as compared to the control nutrient solution and $50 \mathrm{ml}$ of $\mathrm{KCl}$ and $\mathrm{CaCl}_{2} \cdot 2 \mathrm{H}_{2} \mathrm{O}$ were added respectively into the nutrient solution.

\section{Measurement of Fresh Weight (FW) and Dry Weight (DW) of Shoot and Root}

All plants were harvested after 6 weeks of different $\mathrm{NO}_{3}{ }^{-}$ treatments. After plant removal from the troughs $(09: 00 \mathrm{~h}$ to 10:00h), the sponge cube was removed from individual root system carefully. Each plant was divided into shoot and root. The shoots and roots were weighed separately before wrapping in aluminum foil. The DW of shoots and roots were recorded after they were dried at $80{ }^{\circ} \mathrm{C}$ for 4 days.

\section{Analysis of Root Morphology}

Root morphology was analysed with WIN MAC RHIZO V 3.9 programme after different $\mathrm{NO}_{3}^{-}$treatments for two weeks. Total root length, surface area, average root diameter and number of root tips were determined by the programme.
Measurements of Light-Saturated Photosynthetic $\mathrm{CO}_{2}$ Assimilation ( $\mathrm{A}_{\text {sat }}$ ) and Stomatal Conductance ( $\mathrm{g}_{\mathrm{s} \text { sat }}$ )

Five weeks after different $\mathrm{NO}_{3}{ }^{-}$treatments, $A_{\text {sat }}$ and $g_{s}$ sat of attached fully expanded leaves (the 6th leaves from the base) were recorded simultaneously between 09:00 $\mathrm{h}$ to 11:00 $\mathrm{h}$ in the greenhouse with an open infrared gas analysis system with a $6-\mathrm{cm}^{2}$ chamber (LI-6400, Biosciences, U.S.). Readings were taken with an LED light source in the wavelength range 660 to $675 \mathrm{~nm}$ under a PPFD of $1200 \mu \mathrm{mol} \mathrm{m}$ $\mathrm{s}^{-1}$. Average relative humidity and ambient $\left[\mathrm{CO}_{2}\right]$ in the chamber were $70 \%$ and $400 \pm 5 \mu \mathrm{mol} \mathrm{mol}{ }^{-1}$, respectively. Leaf chamber temperature was set according to greenhouse conditions $\left(30-32{ }^{\circ} \mathrm{C}\right)$. It usually took about $3-5 \mathrm{~min}$ for both $A_{\text {sat }}$ and $g_{s}$ sat to be stable. For each treatment, five readings were obtained from five different leaves of five different plants $(n=5)$.

\section{Determination of $\mathrm{Chl}$}

Fresh tissues of $0.5 \mathrm{~g}$ from each treatment were soaked in $5 \mathrm{ml}$ of $\mathrm{N}$, N-dimethylformamide (N, N-DMF, Sigma Chemical Co.) in the dark for $48 \mathrm{~h}$ at $4{ }^{\circ} \mathrm{C}$. The absorptions of Chl were measured at $647 \mathrm{~nm}$ and $664 \mathrm{~nm}$, respectively using a spectrophotometer (Du 650, Beckman, USA). Total Chl content was calculated according to Welburn [19].

\section{Determination of $\mathrm{NO}_{3}^{-}$}

Dried plant tissue of $0.03 \mathrm{~g}$ was ground with deionised water and then incubated at $37{ }^{\circ} \mathrm{C}$ for $2 \mathrm{~h}$. Prior to analysis, sample turbidity was removed by filtration through a $0.45 \mathrm{~m}$ pore diameter membrane filter. The $\mathrm{NO}_{3}^{-}$was determined according to Allen [20] using a Flow Injection Analyser (Model QuikChem 8000, Lachat Instruments Inc, Milwaukee, WI, USA). In this measurement, $\mathrm{NO}_{3}{ }^{-}$was first reduced to $\mathrm{NO}_{2}^{-}$by passage of the sample through a copperized cadmium column. The $\mathrm{NO}_{2}^{-}$was then determined by diazotizing with sulfanilamide followed by coupling with $\mathrm{N}-(1-$ naphthyl)ethylenediamine dihydrochloride. The resulting water soluble dye was read at $520 \mathrm{~nm}$.

\section{Determination of Total Reduced N}

For each treatment, dry samples of $0.05 \mathrm{~g}$ from each treatment were placed into a digestion tube with a Kjeldahl tablet and $5 \mathrm{ml}$ of concentrated sulfuric acid. After the digestion was completed, the $\mathrm{N}$ content was determined by a Kjeltec auto 1030 analyser after the digestion was completed.

\section{Determination of Maximal Nitrate Reductase (NR) Activity}

Leaf or root samples (harvested during light period between 09:30 to $10: 30 \mathrm{~h}$ ) were immediately frozen in liquid nitrogen after weighed and stored at $-80^{\circ} \mathrm{C}$ until use. Tissues were extracted using Tris- $\mathrm{HCl}$ buffer $(\mathrm{pH}$ 8.5) developed by [21]. A frozen sample of $0.5-1 \mathrm{~g}$ was powdered in liquid nitrogen and ground with $3 \mathrm{ml}$ of extraction buffer, with a mortar and pestle in the presence of $0.2 \mathrm{~g} / \mathrm{g} \mathrm{fw}$ insoluble PVP. The extraction buffer includes $0.25 \mathrm{M}$ Tris- $\mathrm{HCl}$ (pH 8.5), $3 \mathrm{mM}$ dithiothreitol (DTT), $10 \mu \mathrm{M}$ flavin adenine dinucleotide (FAD), $1 \mu \mathrm{M}$ sodium molybdate, $1 \mathrm{mM}$ ethylenediamine-tetra-aceticacid (EDTA). The extracts were cen- 
trifuged at $15,000 \mathrm{~g}$ for $10 \mathrm{~min}$ at $4{ }^{\circ} \mathrm{C}$. NR activity was measured immediately in the supernatant.

In vitro NADH: NR activity assay was derived from Kaiser and Huber with modification. The maximum activity of NR was determined by assaying NR with $\mathrm{Mg}^{2+}(10 \mathrm{mM})$. In all cases, the total reaction medium was $700 \mu 1$ which contained $50 \mathrm{mM}$ Hepes- $\mathrm{KOH}(\mathrm{pH}$ 7.5), $1 \mathrm{mM}$ DTT, $10 \mu \mathrm{M}$ FAD, $10 \mathrm{mM} \mathrm{KNO}_{3}, 0.2 \mathrm{mM}$ NADH, NR extraction, and 10 $\mathrm{mM} \mathrm{MgCl}_{2}$ or $15 \mathrm{mM}$ EDTA. The reaction was started by adding of $200 \mu \mathrm{lNR}$ extraction. Incubation was performed at $25^{\circ} \mathrm{C}$ for $20 \mathrm{~min}$, and the reaction was then terminated by the addition of an equal volume $(700 \mu 1)$ of sulfanilamide $(1 \%$ $(\mathrm{w} / \mathrm{v})$ in $3 \mathrm{~N} \mathrm{HCl})$ and the naphthylethylenediamine dihydrochloride $(0.02 \% \mathrm{w} / \mathrm{v})$. After $30 \mathrm{~min}$ at room temperature, the absorbance at $540 \mathrm{~nm}\left(\mathrm{~A}_{540}\right)$ of all the samples was read. The blank was identical to the samples. NR activity was expressed as nmol nitrite $\mathrm{min}^{-1} \mathrm{mg}^{-1}$ protein.

\section{Statistical Analysis}

Means across all treatments were discriminated using ANOVA and followed by Tukey's multiple comparison test. The difference among the means were considered significant at $p<0.05$. All statistical analyses were conducted using MINITAB software (MINITAB, Inc., Release 15, 2007).

\section{RESULTS}

\section{FW and DW of Shoots and Roots}

At harvest (6 weeks after transplanting), the FW and DW of both RILs under $+\mathrm{N}$ and $-\mathrm{N}$ treatments declined significantly compared to those of full $\mathrm{N}$ plants (Figs. 1A to 1D). Figs. (1E and 1F) show that shoot/root FW ratio was higher in both RILs grown under $+\mathrm{N}$ compared to full $\mathrm{N}$ and $-\mathrm{N}$ treatments. The shoot/root DW ratio of $168 \mathrm{HS}$ plants under full $\mathrm{N}$ was lower than those grown under $+\mathrm{N}$ and $-\mathrm{N}$ conditions. However for $200 \mathrm{HR}$ plants, the highest shoot/root $\mathrm{DW}$ ratios were found in $+\mathrm{N}$ plants followed by full $\mathrm{N}$ plants and the lowest shoot/root DW ratio were obtained from $-\mathrm{N}$ plants (Fig. 1F).

\section{Root Morphology}

Reductions in root length (Fig. 2A), root surface area (Fig. 2B) and number of root tips (Fig. 2C) were observed in 168 HS plants under both $+\mathrm{N}$ and $-\mathrm{N}$ treatments. However, there were no significant differences in root diameters
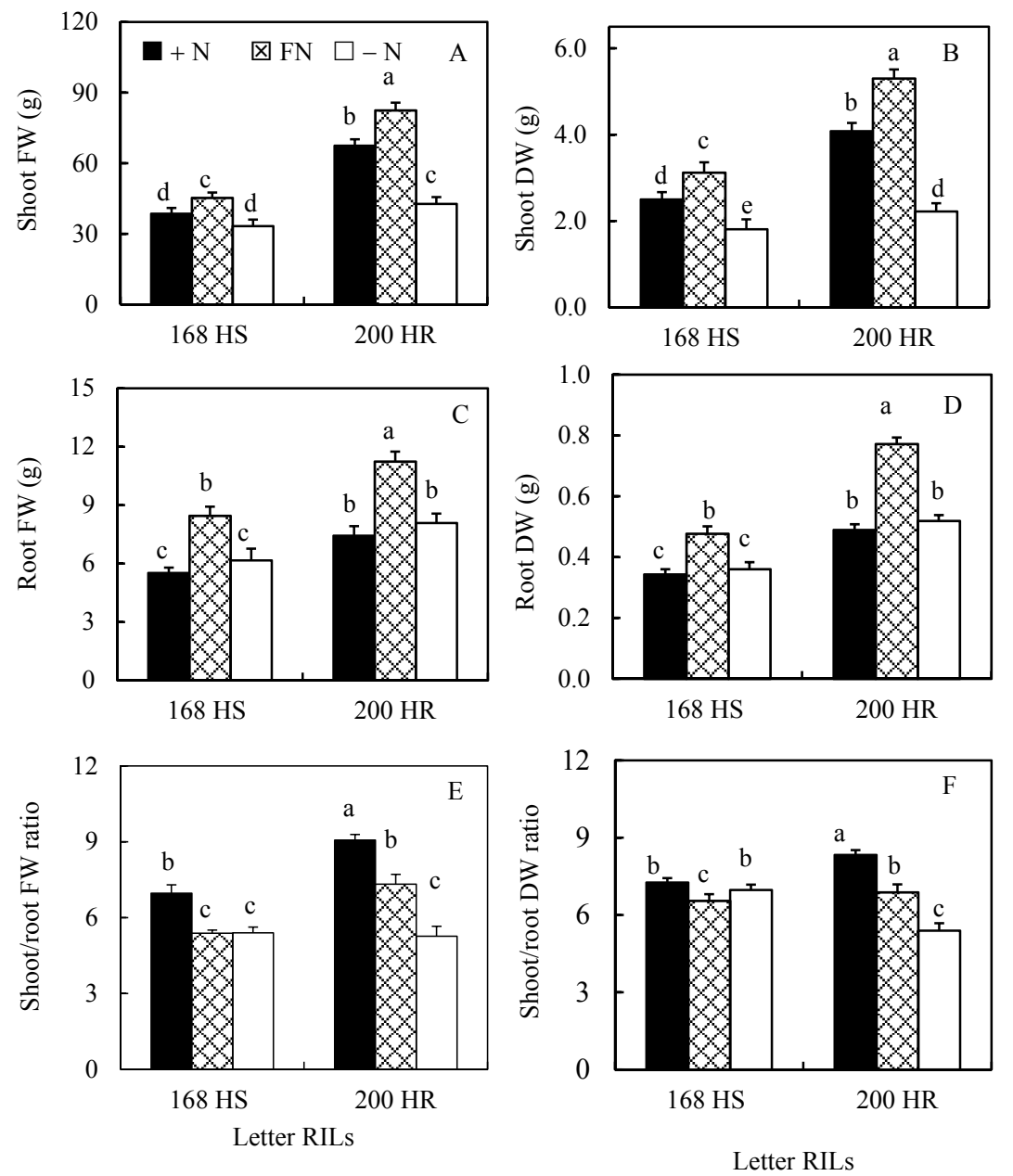

Fig. (1). Shoot FW and DW (A, B), root FW and DW (C, D), shoot/root ratio FW and DW (E, F) of 168 HS and 200 HR lettuce RILs grown under different $\mathrm{N}$ treatments for 6 weeks. Each bar is a mean of 5 measurements. Vertical bars represent standard error. Means with different letters above the bars are statistically different $(p<0.05)$ by Tukey's multiple comparison test. 
among the different $\mathrm{N}$ treatments in $168 \mathrm{HS}$ plants (Fig. 2D). For $200 \mathrm{HR}$ plants, all plants had similar values of all root parameters regardless of $\mathrm{N}$ treatments (Fig. 2).

\section{$A_{\text {sat }}, g_{\text {s sat }}$ and Chl Content}

Fig. (3) shows $A_{\text {sat }}$ and $g_{s}$ sat of both lettuce RILs that were grown under different $\mathrm{N}$ treatments for 5 weeks. $A_{\text {sat }}$ and $g_{s \text { sat }}$ of different plants ranging from $11-12.5 \mu \mathrm{mol}$ $\mathrm{CO}_{2} \mathrm{~m}^{-2} \mathrm{~s}^{-1}$ and $1080-1200 \mathrm{mmol} \mathrm{H}_{2} \mathrm{O} \mathrm{m}^{-2} \mathrm{~s}^{-1}$, respectively. However, statistically, there were no significant differences for both $A_{\text {sat }}$ (Fig. 3A) and $g_{s \text { sat }}$ (Fig. 3B) among the different $\mathrm{N}$ treatments in both lettuce RILs. Total Chl content was higher in $200 \mathrm{HR}$ plants than in $168 \mathrm{HS}$ plants. For instance, the total Chl contents for $200 \mathrm{HR}$ and $168 \mathrm{HS}$ plants were, respectively, about $2000-2060 \mu \mathrm{g} \mathrm{g}^{-1} \mathrm{FW}$ and $1700-1870$ $\mu \mathrm{g} \mathrm{g}^{-1}$ FW. However, for each RIL, all plants under different
$\mathrm{N}$ treatments had similar total Chl content (Fig. 4A) and Chl $\mathrm{a} / \mathrm{b}$ ratios, ranging from $2.5-2.7$ (Fig. 4B).

\section{$\mathrm{NO}_{3}{ }^{-}$, Total Reduced $\mathrm{N}$ Concentration and Maximal NR Activity}

For both lettuce RILs, shoot $\mathrm{NO}_{3}^{-}$concentration was highest in $+\mathrm{N}$ plants followed by full $\mathrm{N}$ plants and $-\mathrm{N}$ plants had the lowest values (Fig. 5A). However, no differences were found in root $\mathrm{NO}_{3}{ }^{-}$concentrations between $+\mathrm{N}$ and full $\mathrm{N}$ plants but root $\mathrm{NO}_{3}{ }^{-}$concentration was significantly lower in $-\mathrm{N}$ plants compared to $+\mathrm{N}$ and full $\mathrm{N}$ plants (Fig. 5B). For shoot total reduced $\mathrm{N}$, $+\mathrm{N}$ plants had significantly higher concentration in both RILs than those of full $\mathrm{N}$ and $-\mathrm{N}$ plants (Fig. 5C). All plants had similar root total reduced $\mathrm{N}$ concentrations except for $168 \mathrm{HS}$ under $-\mathrm{N}$ condition, which had significantly lower total reduced $\mathrm{N}$ concentrations (Fig.
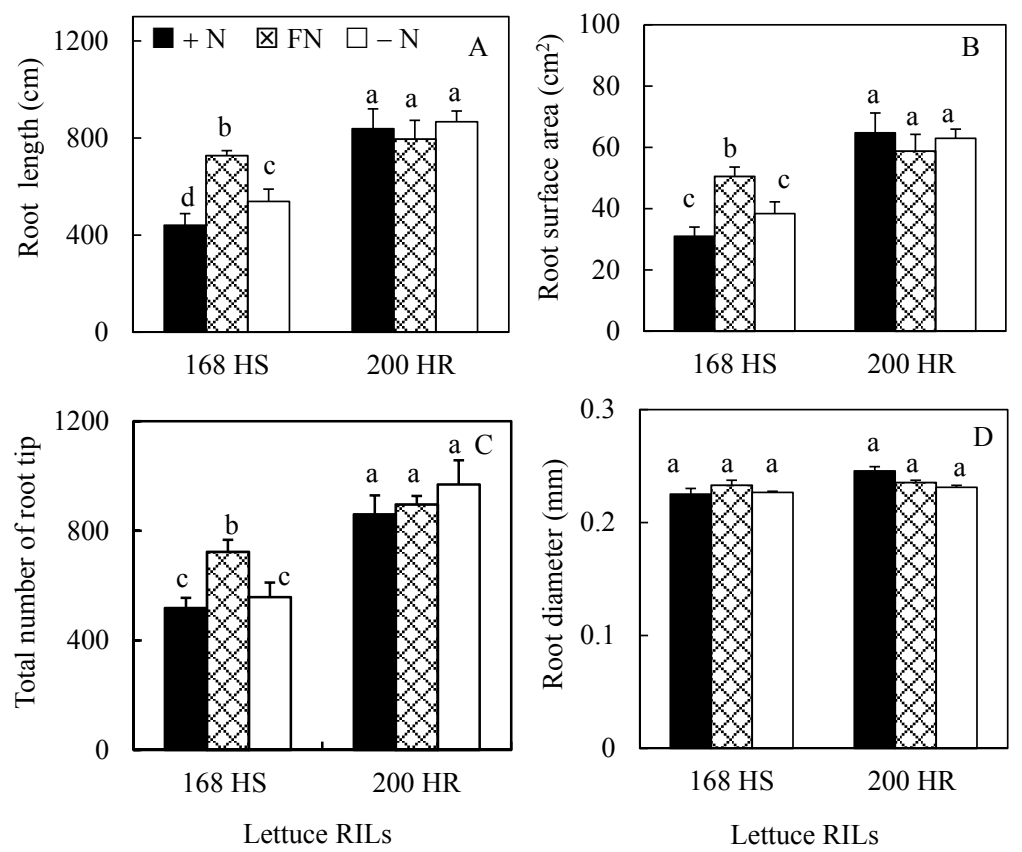

Fig. (2). Root length (A), root surface area (B), total number of root tips (C) and root diameter of 168 HS and 200 HR lettuce RILs grown under different $\mathrm{N}$ treatments for 6 weeks. Each bar is a mean of 5 measurements. Vertical bars represent standard error. Means with different letters above the bars are statistically different $(p<0.05)$ by Tukey's multiple comparison test.
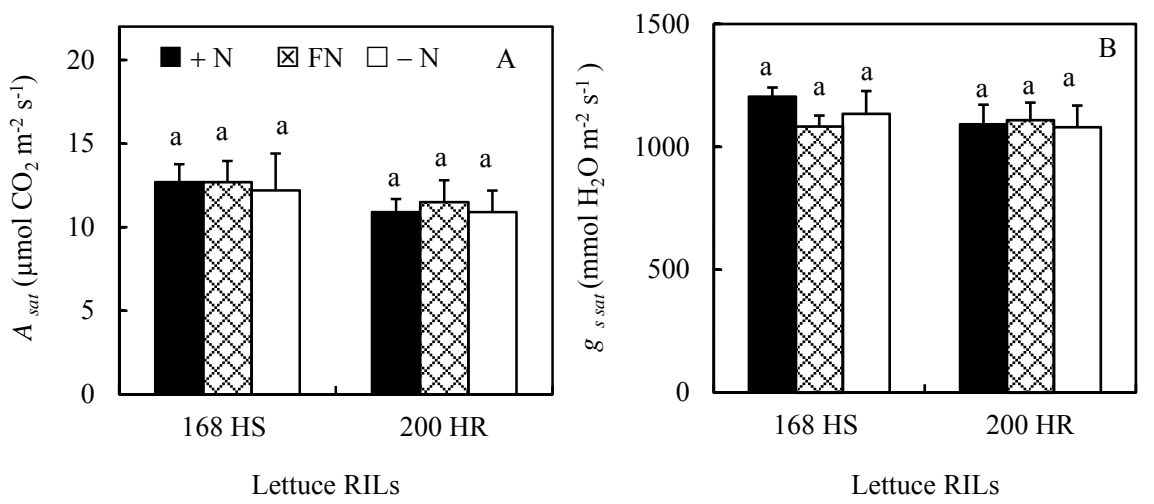

Fig. (3). $A_{\text {sat }}$ (A) and $g_{s \text { sat }}($ B) of $168 \mathrm{HS}$ and $200 \mathrm{HR}$ lettuce RILs grown under different $\mathrm{N}$ treatments for 5 weeks. Each bar is a mean of 5 measurements. Vertical bars represent standard error. Means with different letters above the bars are statistically different $(p<0.05)$ by Tukey's multiple comparison test. 
5D). Changes in shoot maximal NR activity in both RILs and in root maximal NR activity in $200 \mathrm{HR}$ plants were very similar to those of total reduced N (Fig. 6A). However, 168 HS plants had significantly higher root maximal NR activity under $+\mathrm{N}$ conditions compared to those under full $\mathrm{N}$ and $-\mathrm{N}$ conditions (Fig. 6B).
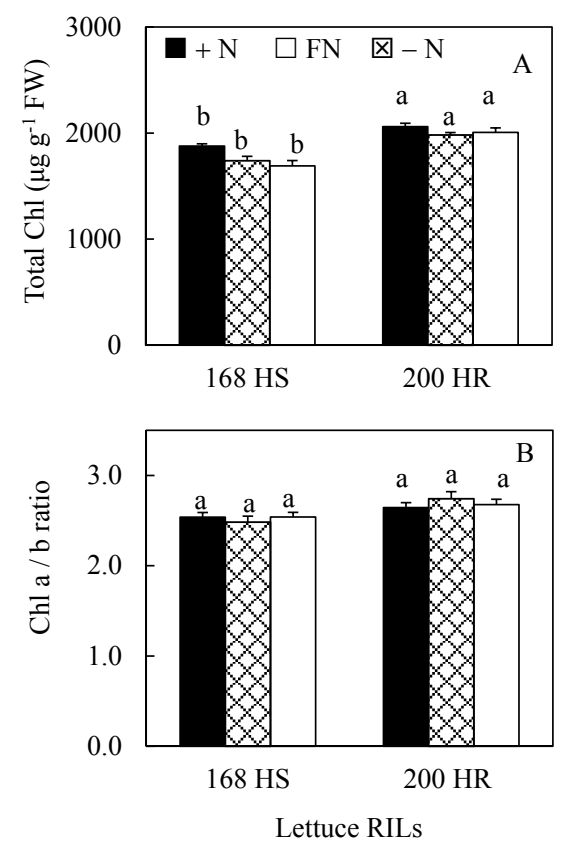

Fig. (4). Total $\mathrm{Chl}$ content (A) and $\mathrm{Chl} \mathrm{a} / \mathrm{b}$ ratio (B) of $168 \mathrm{HS}$ and 200 HR lettuce RILs grown under different $\mathrm{N}$ treatments for 6 weeks. Each bar is a mean of 5 measurements. Vertical bars represent standard error. Means with different letters above the bars are statistically different $(p<0.05)$ by Tukey's multiple comparison test.
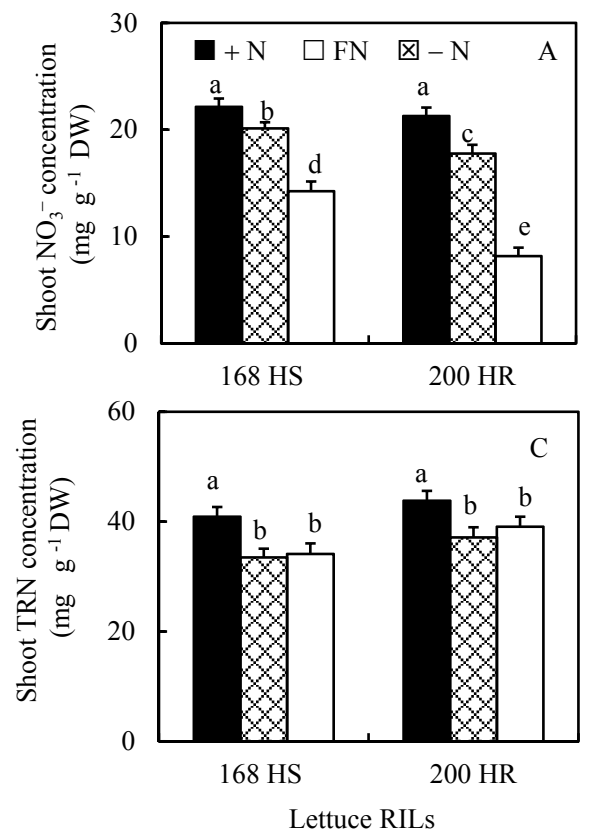

\section{DISCUSSION}

In present study, the results demonstrated that by limiting $\mathrm{N}$ supply in the nutrient solution, the FW and DW of the shoots and roots declined significantly for both $168 \mathrm{HS}$ and $200 \mathrm{HR}$ plants (Figs. 1A to 1D) as less $\mathrm{NO}_{3}{ }^{-}$is made available to the lettuce plants (Figs. 5A, 5B). $\mathrm{N}$ deficiency most frequently limits plant growth $[1,2]$. However, subjecting to $\mathrm{N}$ deficient but constant low $\mathrm{N}$ concentrations in the root medium, plants normally reduce shoot growth rate without affecting photosynthesis [22-24]. This was also observed in the present study (Fig. 3), that was, no significant differences in photosynthetic gas exchanges (Fig. 3) and total Chl content (Fig. 4) among the different $\mathrm{N}$ treatments were observed. It was reported that when plants supplied with limited N, newly fixed carbon is mainly channeled toward the below part of the plants so that root elongation can be stimulated [25]. This results in a decrease in the shoot/root biomass ratio [24, 26, 27]. The results of both lettuce RILs in the present study (Fig. 1E) supported these earlier findings. Walker et al. [2] reported that lettuce growth increase when the external $\mathrm{N}$ supply increases. In the present study, it was surprise to see that increase the supply of $\mathrm{NO}_{3}{ }^{-}$(+N plants) also resulted in the decreases of shoot and root productivity in both lettuce RILs (Figs. 1A to 1D) although there was no change in photosynthetic gas exchange (Fig. 3) compared to those of full $\mathrm{N}$ plants.

Both intrinsic factors such as the supply of photoassimilate and extrinsic factors including $\mathrm{NO}_{3}{ }^{-}$availability affect growth and development of a root system [5-10, 28-30]. In the present study, it was shown that by changing $\mathrm{N}$ (both $+\mathrm{N}$ and $-\mathrm{N}$ treatments) to the $168 \mathrm{HS}$ plants changed the root morphology in terms of reduction in their root length and root surface area and the number of root tips (Fig. 2). Zhang et al. [8] reported that low $\mathrm{NO}_{3}{ }^{-}$availability suppressed the
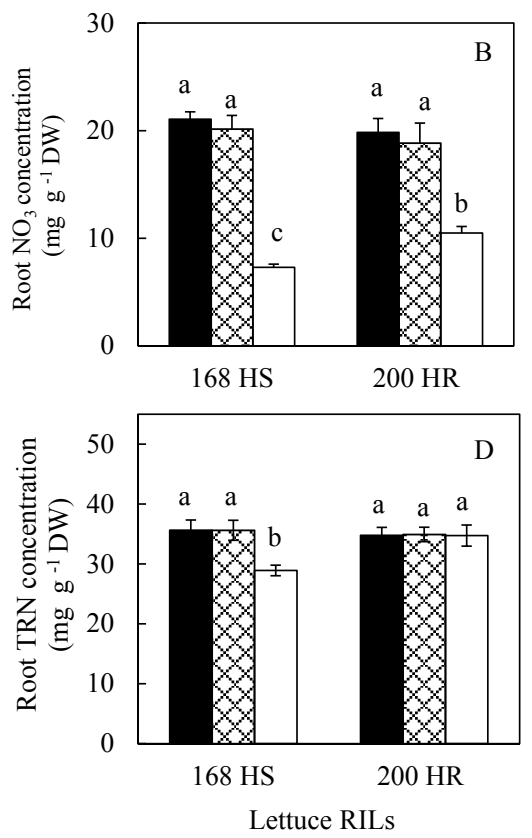

Fig. (5). Shoot and root $\mathrm{NO}_{3}{ }^{-}(\mathbf{A}, \mathbf{B})$ and total reduced $\mathrm{N}(\mathbf{C}, \mathbf{D})$ concentrations of $168 \mathrm{HS}$ and 200 HR lettuce RILs grown under different $\mathrm{N}$ treatments for 5 weeks. Each bar is a mean of 5 measurements. Vertical bars represent standard error. Means with different letters above the bars are statistically different $(p<0.05)$ by Tukey's multiple comparison test. 

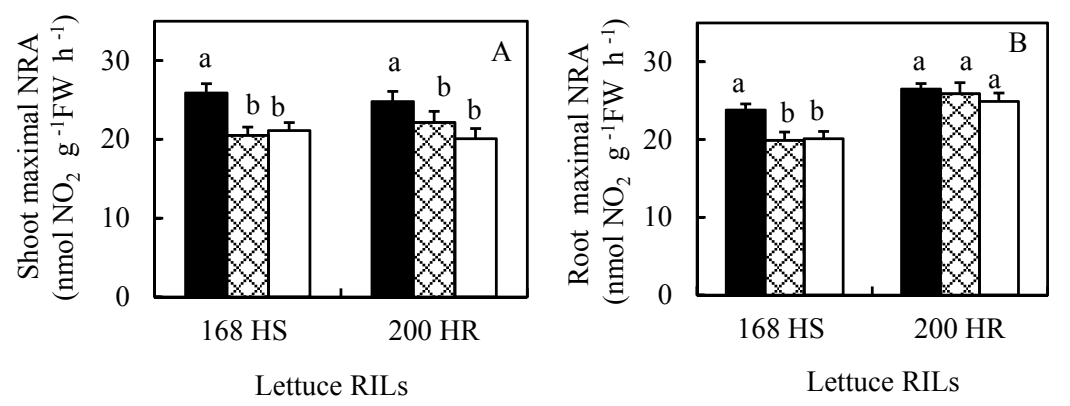

Fig. (6). Shoot (A) and root (B) maximal NR activity of 168 HS and 200 HR lettuce RILs grown under different N treatments for 5 weeks. Each bar is a mean of 5 measurements. Vertical bars represent standard error. Means with different letters above the bars are statistically different $(p<0.05)$ by Tukey's multiple comparison test.

initiation of lateral root. However, their results also showed that high $\mathrm{NO}_{3}^{-}$concentration stimulate the initiation and elongation of lateral root due to high photosynthate partitioned to the roots [9]. In the present study, although all 168 HS plants had very similar photosynthetic rate higher shoot/root $\mathrm{FW}$ ratio grown under $+\mathrm{N}$ compared to full $\mathrm{N}$ and $-\mathrm{N}$ treatments imply that the supply of photosynthetic product from the shoot could in part responsible for the changes of root morphology. High $\mathrm{NO}_{3}{ }^{-}$availability in Arabidopsis plants could cause localized stimulatory effects on lateral root proliferation and a systemic inhibitory effect on the root elongation indicating that there are signalling pathways that regulate root development in response to the availability of $\mathrm{NO}_{3}{ }^{-}$[8]. However, our results are controversy with those of Zhang et al. [8]. In this study, hydroponic system is used to cultivate the lettuce plants. Roots were immersed in the nutrient solutions at all time. There is no necessity to increase root length as well as root surface area [8]. The resource optimization theory about plants which tend to allocate relatively lesser to the roots when nutrient availability increases [10] is reaffirmed. Zhang and Forde [31] reported that the LR of Arabidopsis showed two contrasting responses to high $\mathrm{NO}_{3}{ }^{-}$. Uniformly high $\mathrm{NO}_{3}{ }^{-}$reduces lateral root elongation throughout the root system. However, in plants grown on a low $\mathrm{NO}_{3}{ }^{-}$concentration, exposure of a section of the primary root to high $\mathrm{NO}_{3}{ }^{-}$induces a local stimulation of LR elongation [31]. In the present study, the $+\mathrm{N}$ plants were grown under uniformly high $\mathrm{NO}_{3}{ }^{-}$concentration. However, for 200 HR plants, all plants had similar values of all root parameters regardless of $\mathrm{N}$ treatments (Fig. 2). The development of root for two different heat resistant RILs was affected not only by $\mathrm{NO}_{3}{ }^{-}$availability but also other external factors such temperature, especially the root-zone temperature [17]. Using other lettuce cultivars, our previous studies showed that high root-zone temperature inhibited root growth and development [32-34] due the alternation of photoassimilate partitioning [35].

$\mathrm{NO}_{3}^{-}$plays a part in NR post-translational regulation [16]. On the other hand, $\mathrm{NR}$ activity is affected by $\mathrm{NO}_{3}{ }^{-}$and photosynthesis $[13,15]$. There were significant increases of shoot $\mathrm{NO}_{3}{ }^{-}$and total reduced $\mathrm{N}$ concentrations in both RILs exposed to $+\mathrm{N}$ treatment (Figs. 5A, 5C). This could be due to a higher of conversion of $\mathrm{NO}_{3}{ }^{-}$into reduced $\mathrm{N}$ by NR [14]. These results corresponded well with a significant higher maximal NR activity in the shoots of RILs under $+\mathrm{N}$ conditions compared to those of full $\mathrm{N}$ and $-\mathrm{N}$ plants (Fig. 6). Although shoot $\mathrm{NO}_{3}{ }^{-}$concentrations in both RILs supplied with lower $\mathrm{NO}_{3}^{-}$(-N plants) were lower compared to that of full $\mathrm{N}$ plants, the $-\mathrm{N}$ plants had similar total reduced $\mathrm{N}$ concentrations (Figs. 5C, 5D) and NR activity (Fig. 6) as full $\mathrm{N}$ plants of both RILs. $\mathrm{NO}_{3}{ }^{-}$uptake and assimilation is an energy demand process [3, 13, 15]. Chen et al. [36] reported that NR activity might be induced only when reaching a threshold of $\mathrm{NO}_{3}^{-}$concentration for leafy vegetables. This may contribute to the high maximal NR activity in both shoot and roots of both RILs that had much higher shoot and root $\mathrm{NO}_{3}{ }^{-}$concentration grown under $+\mathrm{N}$ condition. Carbon metabolism seems to be essential both for provision of energy for $\mathrm{NO}_{3}{ }^{-}$uptake and for regulation of $\mathrm{NO}_{3}{ }^{-}$ assimilation [37]. In the present study, $\mathrm{High} \mathrm{NO}_{3}{ }^{-}$uptake and conversion in $+\mathrm{N}$ plants; and high $\mathrm{NO}_{3}{ }^{-}$assimilation with lower $\mathrm{NO}_{3}{ }^{-}$concentration could be at the costs of new fixed carbon and thus reduce the accumulation of biomass in both $+\mathrm{N}$ and $-\mathrm{N}$ plants (Fig. 1).

\section{CONCLUSION}

Both excessive and limited $\mathrm{NO}_{3}{ }^{-}$supply reduced the productivity of shoots and roots. It is not economically practical to supply higher or lesser $\mathrm{NO}_{3}{ }^{-}$to the growth media in order to increase or to maintain the productivity of HR and HS lettuce RILs, respectively. There was no clear correlation between $\mathrm{NO}_{3}{ }^{-}$availability and root morphology. However, it was evident that the responses of two different heat resistant lettuce RILs to $\mathrm{NO}_{3}{ }^{-}$availability were different in terms of root length, root surface area and the number of roots tip. There are multiple factors such as $\mathrm{NO}_{3}{ }^{-}$availability, the supply of photoassimilate and temperature, which are responsible for lettuce root growth and development. Lower biomass accumulation in both $+\mathrm{N}$ and $-\mathrm{N}$ plants could be due to the high energy demand for both $\mathrm{NO}_{3}^{-}$uptake and assimilation.

\section{CONFLICT OF INTEREST}

The authors confirm that this article content has no conflict of interest.

\section{ACKNOWLEDGEMENTS}

This project was supported by the Academic Research Fund (RI 9/10 HJ), Ministry of Education, Singapore. We 
also thank University of California, Davis Genome Center GBSF for providing the seeds of lettuce RILs.

\section{REFERENCES}

[1] Marschner H. Mineral nutrition of higher plants. $2^{\text {nd }}$ ed. London: Academic Press 1995

[2] Walker RL, Burns IG, Moorby J. Responses of plant growth rate to nitrogen supply: a comparison of relative addition and $\mathrm{N}$ interruption treatments. J Exp Bot 2001; 52: 309-17.

[3] Singh AK, Elvitigala T, Bhattacharyya-Pakrasi M, Aurora R, Ghosh B, Pakrasi HB. Integration of carbon and nitrogen metabolism with energy production is crucial to light acclimation in the Cyanobacterium synechocystis. Plant Physiol 2008; 148: 467-78.

[4] Crawford N, Glass ADM. Molecular and physiological aspects of nitrate uptake in plants. Trends Plant Sci 1998; 3: 389-95.

[5] López-Bucio J, Cruz-Ramírez A, Herrera-Estrella L. The role of nutrient availability in regulating root architecture. Curr Opin Plant Biol 2003; 6: 280-7.

[6] Kraiser T, Gras DE, Gutiérrz AG, González B, Gutiérrz RA. A holistic view of nitrogen acquisition in plants. J Exp Bot 2011; 62: 1455-66.

[7] Little DY, Rao H, Oliva S, Daniel-Vedele F, Krapp A, Malamy JE. The putative high-affinity nitrate transporter NRT2.1 represses lateral root initiation in response to nutritional cues. Proc Natl Acad Sci USA 2005; 102: 13693-8.

[8] Zhang H, Rong H, Pilbeam D. Signalling mechanism underlying the morphological responses of the root system to nitrogen in Arabidopsis thaliana. J Exp Bot 2007; 58: 2329-38.

[9] Drew MC, Saker LR, Ashley TW. Nutrient supply and the growth of seminal root system in barley. J Exp Bot 1973; 24: 1189-202.

[10] Ågren GI, Franklin O. Root:shoot ratios, optimization and nitrogen productivity. Ann Bot 2003; 92: 795-800.

[11] Daniel-Vedele F, Filleur S, Caboche M. Nitrate transport: a key step in nitrate assimilation. Curr Opin Plant Biol 1998; 1: 235-9.

[12] Tsay YF, Chiu CC, Tsai CB, Ho CH, Hsu PK. Nitrate transporters and peptide transporters. FEBS Lett 2007; 581: 2290-300.

[13] Masclaux-Daubresse G, Daniel-Vedele F, Dechorgnat J, Chardon F, Gaufichon L, Suzuki A. Nitrogen uptake, assimilation and remobilization in plants: challenges for sustainable and productive agriculture. Ann Bot 2010; 105: 1141-57.

[14] Scheurwater I, Koren M, Lambers H, Atkin OK. The contribution of roots and shoots to whole plant nitrate reduction in fast- and slow-growing grass species. J Exp Bot 2002; 53: 1635-42.

[15] Lillo C. Signalling cascades integrating light-enhanced nitrate metabolism. Biochem J 2008; 415: 11-9.

[16] Allègre A, Silvestre H, Morard P, Kallerhoff J, Pinelli E. Nitrate reductase regulation in tomato roots by exogenous nitrate: a possible role in tolerance to long term root anoxia. J Exp Bot 2004; 55: 2625-34.

[17] Choong TW, He J, Qin L. Dodd IC. Identifying heat-resistant recombinant inbred lines (RILs) of lettuce in the tropics: Productivity and root phenotyping. Acta Hort 2013; 1004: 173-80.

[18] He J, Seet LTL, Choong TW, Qin L, Dodd IC. Photosynthesis and nitrogen metabolism of heat-resistant and heat-sensitive recombinant inbred lines (RILs) of lettuce under different root-zone temperatures. Acta Hort 2013; 1004: 165-72.

[19] Welburn AR. The spectral determination of chlorophylls $a$ and $b$, as well as total carotenoids, using various solvents with spectrophotometers of different resolution. J Plant Physiol 1994; 144: 307-13.
[20] Allen SE. Analysis of vegetation and other organic materials. In: Allen SE, Ed. Chemical analysis of ecological materials. Oxford, England: Blackwell Scientific Publication 1989; pp. 46-61.

[21] Kuo T-M, Warner RL, Kleinhofs A. In vitro stability of nitrate reductase from barley leaves. Phytochemistry 1982; 21: 531-3.

[22] Chapin FS, Walter CHS, Clarkson DT. Growth response of barley and tomato to nitrogen stress and its control by abscisic acid, water relations and photosynthesis. Planta 1988; 173: 352-66.

[23] McDonald AJS, Davies WJ. Keeping in touch: responses of the whole plant to deficits in water and nitrogen supply. Adv Bot Res 1996; 22: 229-300.

[24] Anandacoomaraswamy A, DeCosta WAJM, Tennakoon PLK, Van Der Werf A. The physiological basis of increased biomass partitioning to roots upon nitrogen deprivation in young clonal tea $(\mathrm{Ca}-$ mellia sinensis (L.) O. Kuntz). Plant Soil 2002; 238: 1-9.

[25] Smolders E, Merckx R. Growth and shoot: root partitioning of spinach plants as affected by nitrogen supply. Plant Cell Environ 1992; 15: 795-807.

[26] Jarvis SC, Macduff JH. Nitrate nutrition of grasses from steadystate supplies in flowing solution culture following nitrate deprivation and/or defoliation. I. Recovery of uptake and growth and their interactions. J Exp Bot 1989; 40: 965-75.

[27] Scheible W-R, Lauerer M, Schulze E-D, Caboche M, Stitt M. Accumulation of nitrate in the shoot acts as a signal to regulate shootroot allocation in tobacco. Plant J 1997; 11: 671-91.

[28] Forde BG, Lorenzo H. The nutritional control of root development. Plant Soil 2001; 232: 51-68.

[29] Bloom AJ, Meyerhoff PA, Taylor AR, Rost TL. Root development and absorption of ammonium and nitrate from the rhizosphere. J Plant Growth Regul 2002; 21: 416-31.

[30] Porterfield DM. Environmental sensing and directional growth of plant roots. In: Waisel Y, Eshel A, Kafkafi U, Eds. Plant roots: the hidden half. New York: Marcel Dekker 2002; pp. 471-87.

[31] Zhang H, Forde B. An Arabidopsis MADS box gene that controls nutrient-induced changes in root architecture. Science 1998; 279: 407-9.

[32] Tan LP, He J, Lee SK. Effects of root-zone temperature on the root development and nutrient uptake of lactuca sativa L. cv 'Panama' grown in an aeroponic system in the tropics. J Plant Nutr 2002; 25: 297-314.

[33] He J. Impact of root-zone temperature on photosynthetic efficiency of aeroponically grown temperate and subtropical vegetable crops in the tropics. In: Buchner TB, Ewingen NH, Eds. Theory and Applications in Energy, Biotechnology and Nanotechnology. New York: Nova Science Publishers Inc. 2009; pp. 111-44.

[34] He J. Mineral nutrition of aeroponically grown subtropical and temperate crops in the tropics with manipulation of root-zone temperature at different growth irradiances. Plant Stress 2010; 4: 14 30 .

[35] He J, Tan LP, Lee SK. Root-zone temperature effects on photosynthesis, ${ }^{14} \mathrm{C}$-photoassimilate partitioning and growth of temperate lettuce (Lactuca sativa cv. 'Panama') grown in the tropics. Photosynthetica 2009; 47: 95-103

[36] Chen BM, Wang ZH, Li SX, Wang GX, Song HX, Wang XN. Effects of nitrate supply on plant growth, nitrate accumulation, metabolic nitrate concentration and nitrate reductase activity in three leafy vegetables. Plant Sci 2004; 167: 635-43.

[37] Larsson M, Ingemarsson B, Larsson C-M. Photosynthetic energy supply for $\mathrm{NO}_{3}{ }^{-}$assimilation in Scenedesmus. Physiol Plant 1982; 55: 301-8.

(C) He et al.; Licensee Bentham Open.

This is an open access article licensed under the terms of the Creative Commons Attribution Non-Commercial License (http://creativecommons.org/licenses/by-nc/3.0/) which permits unrestricted, non-commercial use, distribution and reproduction in any medium, provided the work is properly cited. 